\title{
Penguatan Positif sebagai Upaya Menumbuhkan Perilaku Disiplin pada Siswa Sekolah Dasar
}

\author{
Yussidah Azmiyatul Haqq \\ Fakultas Psikologi, Universitas Muhammadiyah Malang \\ e-mail: ${ }^{1}$ az.yussidah@gmail.com
}

\begin{abstract}
Discipline can be defined as an indication of one's behavior, that occurs in a regulations of an institute, either written or unwritten. An individual with a selfdiscipline behavior is likely to obey the rules and regulation and is easier ro be ruled than those who don't. There are two ways to get self-discipline for students. Punishment or positive reinforcement. However, positive reinforcement is more reliable because it will give stronger effect to change one's behavior. This research is using a Single Case kind of research with a Quasi Experiment design. This experiment uses guide observations and interviews. The subject in the experiment is a couple of male students who don't have self-discipline. To determine the subject is to use Purposive Sampling. The result of the research is that there is a behaviour change from not having a self-discipline to having a self-discipline after given a treatment. This shows that Positive reinforcement has better effect towards student's self-discipline.
\end{abstract}

KEYWORDS Positive reinforcement, discipline behavior, students

CITATION Haqq, Y. A. (2019). Penguatan positif sebagai upaya menumbuhkan perilaku disiplin pada siswa sekolah dasar. Cognicia, 7, (2), 192-201.

Masa usia dasar adalah periode saat anak-anak berusia 6 hingga 11 tahun. Banyak perkembangan yang dicapai. Umum ditemui bahwa perilaku anak-anak bisa beragam bahkan mengganggu proses belajar dalam kelas. Saat jam pembelajaran, sering ditemui anak-anak yang berlarian atau melakukan kegiatan lain. Anak-anak lebih mudah lelah jika harus duduk lama daripada berlari (Fahey \& Insel (dalam Santrock, 2011))

Seperti yang terjadi pada siswa-siswa kelas 3 SDIT Ahmad Yani, Klojen, Malang. Diketahui terdapat 2 orang siswa laki-laki yang menjadi semacam "troublemaker" di kelas. Dari pengamatan yang dilakukan selama dua minggu, menunjukkan kedua siswa ini kurang bisa menunjukkan perilaku disiplin saat jam belajar, dimana siswa sering menunjukkan perilaku mengobrol dengan teman saat guru mengajar (muncul hampir setiap hari), selalu menunda tugas yang diberikan guru (memilih melakukan kegiatan lain, sehingga siswa terlambat selesai mengerjakan tugas; dimana perilaku ini juga muncul hampir setiap hari), terlambat masuk kelas (dikarenakan lupa waktu dan sempat mengira tidak ada guru sehingga keterusan bermain), dan menoleh kanan kiri serta berbicara dengan teman saat pelaksanaan Shalat Dhuha, sehingga peneliti atau guru harus bergantian menegur siswa sembari membetulkan posisi siswa sebagai bentuk teguran. 
Perilaku disiplin yang mereka lakukan sendiri, terkumpul data sebagai berikut ini: untuk subjek 1, diketahui perilaku memperhatikan guru yang menerangkan di depan kelas, hanya muncul 2 kali dalam satu minggu, bertanya mengenai materi yang tidak dipahami (1 kali muncul), mengerjakan tugas yang diberikan guru dengan segera (3 kali muncul dalam satu minggu), masuk kelas tepat waktu (muncul 4 kali), tertib dalam Shalat Dhuha (muncul 4 kali). Sementara untuk subjek 2, data perilaku disiplin yang terkumpul dalam 1 minggu pengamatan meliputi: memperhatikan guru yang menerangkan di kelas (muncul $1 \mathrm{kali}$ ), dengan segera mengerjakan tugas yang diberikan guru (muncul 2 kali), masuk kelas tepat waktu (muncul 2 kali), tertib atau tidak berlarian di kelas (muncul 3 kali), tertib saat Shalat Dhuha (muncul 2 kali).

Berdasarkan data di atas, terdapat perbandingan bahwa perilaku disiplin siswa tampak muncul jarang-jarang, berbanding dengan pelanggaran peraturan yang dimunculkan siswa, dimana muncul hampir setiap hari. Apabila dibiarkan, maka perilaku tidak disiplin siswa akan menjadi kebiasaan, yang mana akan berpengaruh negatif di masa depannya nanti.

Aktivitas pembelajaran harus dilakukan ditempat yang tenang agar ilmu pengetahuan terserap. Banyak strategi telah diterapkan untuk memunculkan disiplin di sekolah, diantaranya tentang ketegasan yang mengikat dalam penerapan disiplin dan penempatan siswa-siswa dalam kelas alternatif. Namun, strategi-strategi ini kurang maksimal, dan menimbulkan masalah lain (Lassen, Steele, \& Sailor, 2006). Disiplin adalah bentuk rasa patuh pada aturan yang berlaku dalam lingkungan, terutama di sekolah (Hurlock, 1962). Manfaat disiplin meliputi: dapat menata kehidupan bersama, melatih kepribadian, pemaksaan (akibat adanya kesadaran diri), timbulnya hukuman untuk mengendalikan perilaku siswa, serta terciptanya lingkungan yang kondusif untuk aktivitas belajar-mengajar (Tulus, 2004).

Ada dua cara melatih disiplin pada siswa, dengan memberikan hukuman, dan diberikan penguatan positif. Penguatan memiliki tiga peranan penting dalam mengajar anak berperilaku disiplin. Pertama: penguatan sebagai alat untuk mendidik. Sebagaimana suatu tindakan bila dilanggar akan mendapat hukuman dan berarti perilaku tersebut buruk, penghargaan menjadi sebuah konsekuensi bahwa perbuatan yang dilakukan bersifat baik dan akan mendapatkan ganjaran. Dalam hal ini diperlukan batasan yang disepakati bila penghargaan difungsikan untuk mendidik anak (Chalpin, 2011).

Kedua penguatan sebagai motivasi untuk menyetujui sebuah perilaku dalam ranah sosial. Anak akan mengeluarkan reaksi senang dan akan mengulangi lagi perilakunya bila orang-orang di sekitarnya mengeluarkan respon yang baik, dalam hal ini, perilaku tersebut dimaksudkan adalah tindakan disiplin.

Ketiga penguatan positif memperkuat perilaku yang disetujui secara sosial. Ketiadaan sebuah penghargaan, akan menghilangkan motivasi anak berperilaku disiplin. Bila anak diharuskan belajar berperilaku dengan cara yang disetujui secara sosial, maka ia harus merasa bahwa yang ia perbuat akan mendapatkan keuntungan bagi dirinya. Karenanya, penguatan harus dipergunakan dengan sebaik-baiknya untuk membentuk asosiasi yang menyenangkan serta perilaku disiplin yang diharapkan.

Berdasarkan uraian di atas, dapat ditarik kesimpulan bahwa penghargaan terhadap perbuatan baik siswa adalah hal yang penting, dan menjadi alat untuk 
membentuk perilaku disiplin bila rutin dilakukan. Saat seorang anak melakukan perbuatan baik dan mendapatkan reward, dia akan senang sehingga mengulangi lagi perbuatannya terus agar mendapatkan respon yang baik dari guru. Sebab, murid selalu ingin merasa dihargai atas apa yang dia lakukan. Dan penguatan positif memunculkan kecenderungan tentang sikap yang diinginkan, sementara hukuman akan melenyapkan semua sikap tersebut (Abrew dalam Rumfola, 2017).

Para peneliti memberikan penguatan positif dengan frekuensi interval yang telah ditentukan, dengan menerapkan beberapa aturan standar, seperti: duduk di tempat yang telah disediakan, berbicara dengan suara pelan dan jelas, menjaga agar tangan tetap di tempat, duduk dengan postur yang bagus di kelas musik, tetap memperhatikan langkah dan perbuatan murid di koridor, menaruh kertas di tempat yang tepat, menaruh barang-barang di tempat yang rapi, serta mengikuti aturan guru (Hulac dkk 2016). Penelitian lain di Pakistan, 75\% guru di Sekolah Urban setuju bahwa penguatan positif membawa dampak baik bagi siswa. Siswa juga lebih bersemangat dalam belajar setelah diberikan penguatan positif berupa kata-kata yang sopan (Ahmed \& Gill, 2015).

Dalam rangka memberikan penguatan positif secara efektif, guru harus tahu kebutuhan siswa dan memfasilitasinya, sehingga murid akan lebih mudah belajar (Rumfola, 2017). Guru juga perlu mengadakan pendekatan dengan siswa, seperti misalnya menemani siswa saat belajar di kelas, bermain salam tepuk, atau kegiatan non-formal yang bisa mendekatkan satu dengan yang lainnya.

\section{METODE}

Penelitian ini menggunakan jenis penelitian eksperimen subjek tunggal (n-kecil) atau single case, yang bisa juga disebut analisis eksperimental terhadap perilaku dengan desain quasi eksperimen. Dalam hal ini, kontrol ditunjukkan dengan mengatur kondisi eksperimental sedemikian rupa sehingga secara perlahan, perilaku subjek akan berubah sebab ada teknik manipulasi pada variabel independen.

Subjek penelitian berjumlah 2 orang siswa kelas 3 SDIT di Kota Malang berusia 8 tahun yang tidak disiplin dalam pembelajaran, dan tidak patuh pada peraturan di sekolah. Teknik yang digunakan adalah Purposive Sampling, yaitu teknik sampling nonrandom dimana peneliti menetapkan kriteria-kriteria tertentu agar sesuai dengan tujuan penelitian. Adapun kriteria yang ditetapkan dalam penelitian ini adalah siswa yang: 1) Tidak tertib dalam mengikuti pembelajaran, 2) Tidak patuh pada peraturan sekolah.

Penelitian menggunakan 2 variabel, yaitu variabel terikat $(Y)$ dan variabel bebas $(\mathrm{X})$. Variabel terikat adalah perilaku disiplin $(\mathrm{Y})$ sementara variabel bebasnya adalah penguatan positif $(X)$. Penguatan positif adalah semua bentuk respon positif baik verbal maupun non-verbal yang merupakan bagian dari modifikasi perilaku oleh guru kepada siswa sebagai bentuk koreksi. Sedangkan disiplin adalah penunjukan sikap dalam perilaku yang sesuai aturan dalam sebuah instansi, baik tertulis maupun tidak tertulis.

Perilaku disiplin siswa dapat menggunakan skala yang tersusun dari dimensi perilaku disiplin: tertib dalam pembelajaran di sekolah, dan patuh pada peraturan. Dimensi tersebut dijadikan acuan untuk mengukur perilaku disiplin yang selanjutnya 
dipergunakan sebagai guide observasi untuk meneliti perilaku disiplin siswa (Zubaedi, 2011).

Ada tiga prosedur dalam penelitian ini: persiapan, pelaksanaan, dan analisis data. Persiapan dimulai dari perumusan masalah di lapangan dan dikaji dalam lingkup ruang psikologi pendidikan. Dilanjutkan penyusunan proposal penelitian yang didasarkan beberapa sumber: jurnal internasional, jurnal nasional, dan buku. Setelahnya, masuk tahap 2, pelaksanaan penelitian. Tahap dua dilaksanakan dengan mengamati siswa langsung pada saat pembelajaran, dan memberikan intervensi berupa penguatan positif verbal dan non-verbal (ucapan dan perbuatan), serta tingkah laku siswa, dicatatkan dalam skala pengamatan harian yang dilaksanakan selama kurang lebih 13 hari (dalam 3 minggu). Setelah kedua tahapan di atas selesai dilakukan, yang terakhir adalah analisis data dengan metode deskriptif kuantitatif.

\section{HASIL}

Subjek dalam penelitian ini berjumlah dua orang siswa laki-laki kelas 3, yaitu $\mathrm{H}$ dan $Z$ yang berusia 8 tahun. Subjek 1 memiliki tinggi $134 \mathrm{~cm}$ dengan berat badan $29 \mathrm{~kg}$. ia berwajah oval dengan rambut ikal hitam, alis tipis hitam, mata bulat kecil dengan bola mata hitam, hidung agak pedek dengan bibir tebal kecokelatan namun berukuran kecil dan dagunya agak runcing. Telinganya kecil dan sewarna dengan kulitnya yang kekuningan muda (langsat) agak tersembunyi di balik rambut ikal dan tebal.

Subjek 2 bertinggi badan $130 \mathrm{~cm}$ dengan berat $32 \mathrm{~kg}$. Berambut lurus hitam dan jabrik. Wajah bulat dengan kedua pipi tembam, berdahi lebar. Alisnya hitam tidak terlalu tebal, cenderung jarang. Matanya berukuran sipit namun memanjang. Hidung besar dengan bibir tebal di bagian atas namun bawah tipis, dengan dagu bulat. Kulitnya kuning agak kecokelatan. Bertelinga kecil.

Gambar 1. Grafik Hasil Penelitian Subjek 1

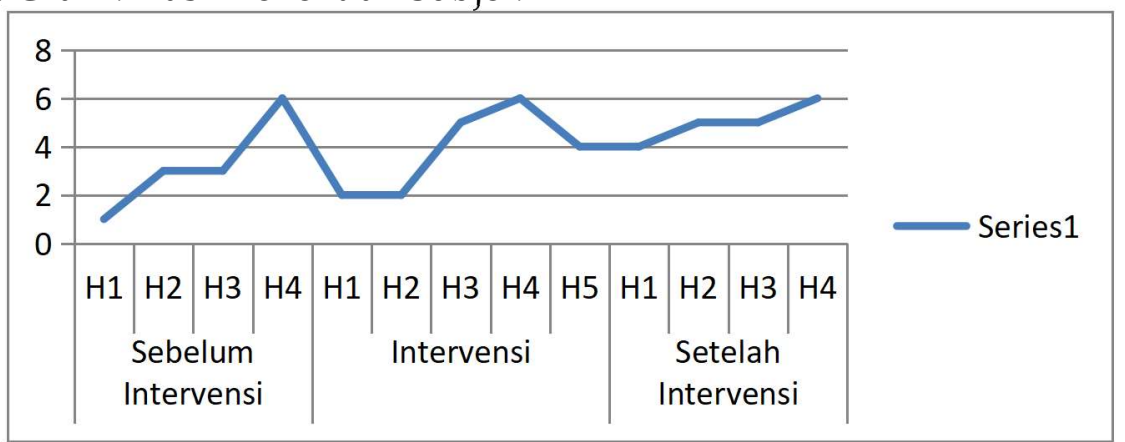

Sebelum intervensi, terlihat subjek memunculkan 1 dari 7 poin. Poin perilaku yang dimunculkannya adalah masuk kelas tepat waktu. Pada hari kedua, terjadi peningkatan sebesar 2 poin menjadi 3, dengan perilaku yang dia munculkan adalah dengan segera mengerjakan tugas yang diberikan guru, masuk kelas tepat waktu, dan tertib saat pelaksanaan Shalat Dhuha (masing-masing kemunculan 1 kali). Hari selanjutnya juga memiliki 3 poin, hanya saja yang muncul yaitu bertanya kepada guru, masuk kelas tepat waktu, dan tertib saat pelaksanaan Shalat Dhuha.

Pada hari keempat, poin yang terkumpul naik menjadi 6, masing-masing pada aspek memperhatikan guru yang menerangkan di kelas (muncul 2 kali), mengerjakan 
tugas yang diberikan guru (muncul 2 kali), masuk kelas tepat waktu dan tertib saat Shalat Dhuha yang masing-masing muncul 1 kali.

Pada masa intervensi hari pertama, siswa memunculkan 2 perilaku, mengerjakan tugas yang diberikan guru dan tertib saat Shalat Dhuha (masing-masing muncul 1 kali). Poin berikut perilaku yang sama juga muncul di hari kedua. Di hari ketiga, muncul perilaku memperhatikan guru yang menerangkan di kelas, mengerjakan tugas dan soal yang diberikan guru, masuk kelas tepat waktu, tidak berlarian di kelas, dan tertib saat Shalat Dhuha (semua aspek ini masing-masing muncul 1 kali).

Pada hari keempat, aspek perilaku memperhatikan guru yang sedang mengajar, muncul 2 kali. Sedangkan mengerjakan tugas yang diberikan guru, masuk kelas tepat waktu, tidak berlarian di kelas dan tertib saat Shalat Dhuha (masing-masing muncul 1 kali). Hari kelima, terjadi penurunan berupa siswa hanya 1 kali memperhatikan guru yang mengajar, siswa mengerjakan tugas yang diberikan guru (perilaku muncul 1 kali), masuk kelas tepat waktu, dan tertib saat pelaksanaan Shalat Dhuha (masing-masing perilaku muncul sebanyak 1 kali).

Di hari pertama setelah pelaksanaan intervensi, terkumpul 4 poin perilaku yang masing-masing: mengerjakan tugas dan soal yang diberikan guru dengan segera (muncul 1 kali), masuk kelas tepat waktu (1 kali muncul), tidak berlarian di kelas (1 kali muncul), dan 1 kali tertib saat Shalat Dhuha. Di hari kedua, poin yang terkumpul 5 perilaku dengan rincian memperhatikan guru yang menerangkan (1 kali), mengerjakan tugas dengan segera, tepat waktu masuk kelas, tertib atau tidak berlarian di kelas, dan tertib saat pengerjaan Shalat Dhuha.

Hari ketiga, muncul perilaku siswa sudah bisa memperhatikan guru yang menerangkan di depan kelas ( 1 kali muncul) dan bertanya mengenai tugas yang tidak dia pahami (juga muncul 1 kali), mengerjakan tugas dengan segera serta tertib Shalat Dhuha (kesemuanya muncul 1 kali). Hari keempat, poin perilaku yang muncul lebih tinggi dari lainnya, total 6 poin: memperhatikan guru yang menerangkan (muncul 2 kali), mengerjakan tugas yang diberikan guru dan masuk kelas tepat waktu (masingmasing 1 kali muncul), 1 kali tertib atau tidak berlarian di kelas, dan tertib saat Shalat Dhuha.

Gambar 2. Grafik Hasil Penelitian Subjek 2

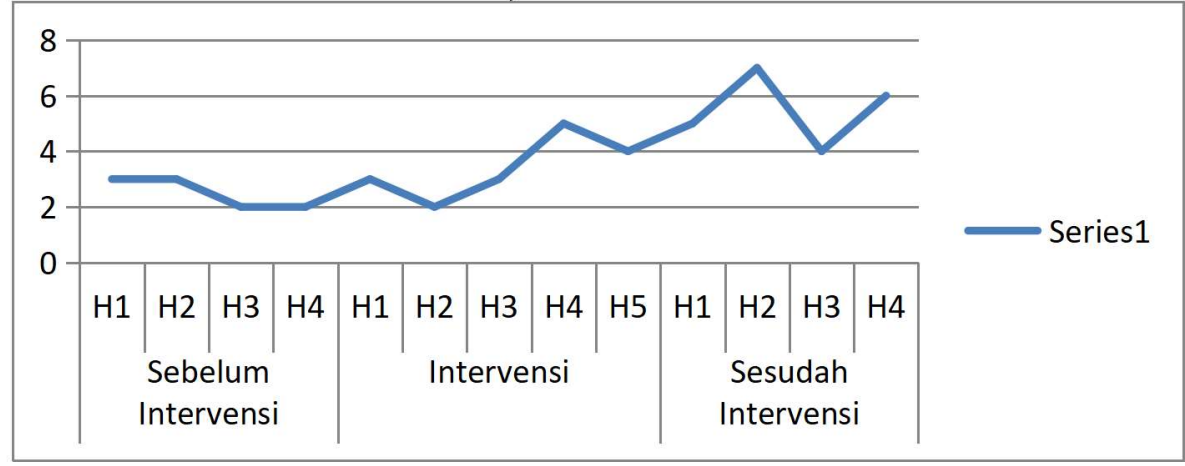

Pada hari pertama, poin yang terkumpul adalah 3 dengan rincian: siswa segera mengerjakan tugas yang diberikan guru (muncul 1 kali), masuk kelas tepat waktu (muncul 1 kali), dan tidak berlarian di kelas. Hari kedua juga terkumpul 3 poin 
perilaku yang muncul, namun aspek perilaku yang muncul kali ini berbeda dengan hari sebelumnya: mengerjakan dengan segera tugas yang diberikan guru, tidak berlarian di kelas, dan tertib saat Shalat Dhuha. Hari ketiga, poin yang muncul hanya 2, yaitu memperhatikan guru yang mengajar dan tertib saat Shalat Dhuha (semua muncul 1 kali). Hari keempat skor sama dengan hari ketiga, yaitu 2: masuk kelas tepat waktu dan tidak berlarian di kelas. Masing-masing perilaku juga muncul 1 kali.

Pada hari pertama intervensi, terdapat 3 poin yang terkumpul: 1 kali siswa memperhatikan guru yang menerangkan, segera mengerjakan soal yang diberikan (1 kali muncul), dan tertib saat Shalat Dhuha (juga muncul 1 kali). Pada hari kedua terdapat penurunan 1 poin dengan jumlah poin yang muncul hanya 2: 1 kali mengerjakan tugas yang diberikan guru dan 1 kali tertib saat Shalat Dhuha. Terdapat kenaikan 1 poin menjadi 3 di hari ketiga, dengan aspek: memperhatikan guru yang menerangkan pelajaran (1 kali), masuk kelas tepat waktu (1 kali), dan tidak berlarian di kelas (juga muncul 1 kali).

Hari keempat, terkumpul 5 poin dan aspek yang muncul menjadi lebih banyak, dengan rincian: memperhatikan guru yang mengajar di depan kelas (1 kali muncul), segera mengerjakan tugas yang diberikan (1 kali muncul). Selain itu, aspek masuk kelas tepat waktu, tidak berlarian di kelas, dan tertib saat Shalat Dhuha, masingmasing muncul dengan frekuensi 1 kali. Hari terakhir intervensi, poin yang terkumpul turun menjadi 4: 1 kali memperhatikan guru yang mengajar, dengan segera mengerjakan tugas yang diberikan guru, masuk kelas tepat waktu, dan tertib saat Shalat Dhuha. Masing-masing aspek perilaku, muncul 1 kali pada subjek 2.

Pada hari pertama setelah intervensi, terkumpul 5 poin perilaku yang muncul dari subiek 2, meliputi: bertanya kepada guru mengenai tugas yang tidak dimengerti, mengerjakan tugas yang diberikan guru (dengan segera), masuk kelas tepat waktu, tidak berlarian di kelas, dan tertib saat Shalat Dhuha. Semua perilaku muncul dengan frekuensi masing masing 1 kali.

Hari kedua, terkumpul 7 poin: memperhatikan guru yang menerangkan (muncul 2 kali), bertanya kepada guru mengenai materi yang tidak dimengerti, mengerjakan tugas yang diberikan guru (muncul 1 kali), masuk kelas tepat waktu (muncul 1 kali), tidak berlrian di kelas (muncul 1 kali), tertib saat Shalat Dhuha (muncul 1 kali). Dihari ketiga, terjadi penurunan poin. Jumlah poin perilaku yang terkumpul adalah 4 , dengan rincian: satu kali memperhatikan guru yang menerangkan di depan kelas dan mengerjakan tugas yang diberikan guru, 1 kali masuk kelas tepat waktu dan tertib saat Shalat Dhuha.

Hari keempat, terdapat kenaikan dengan jumlah perilaku yang muncul bertotal 6 poin. Diantaranya: satu kali (memperhatikan guru yang menerangkan di depan kelas), dua kali muncul (untuk aspek perilaku mengerjakan tugas yang diberikan guru), satu kali (masuk kelas tepat waktu), satu kali (tidak berlarian di kelas), dan satu kali (tertib saat pelaksanaan Shalat Dhuha).

Tabel 1. Hasil Penelitian Subjek 1

Sebelum Intervensi $\quad$ Masa Intervensi $\quad$ Setelah Intervensi




\begin{tabular}{|c|c|}
\hline $\begin{array}{l}\text { Subjek tidak pernah } \\
\text { memperhartikan guru } \\
\text { yang menerangkan di } \\
\text { depan kelas. } \\
\text { Subjek jarang bertanya } \\
\text { mengenai materi yang } \\
\text { tidak dia pahami. } \\
\text { Subjek jarang mau } \\
\text { segera mengerjakan } \\
\text { tugas dan masih } \\
\text { berlarian di kelas. } \\
\text { Namun, subjek selalu } \\
\text { memperlihatkan } \\
\text { ketertiban dan disiplin } \\
\text { pada saat mengerjakan } \\
\text { Shalat Dhuha, serta } \\
\text { masuk kelas tepat } \\
\text { waktu. }\end{array}$ & 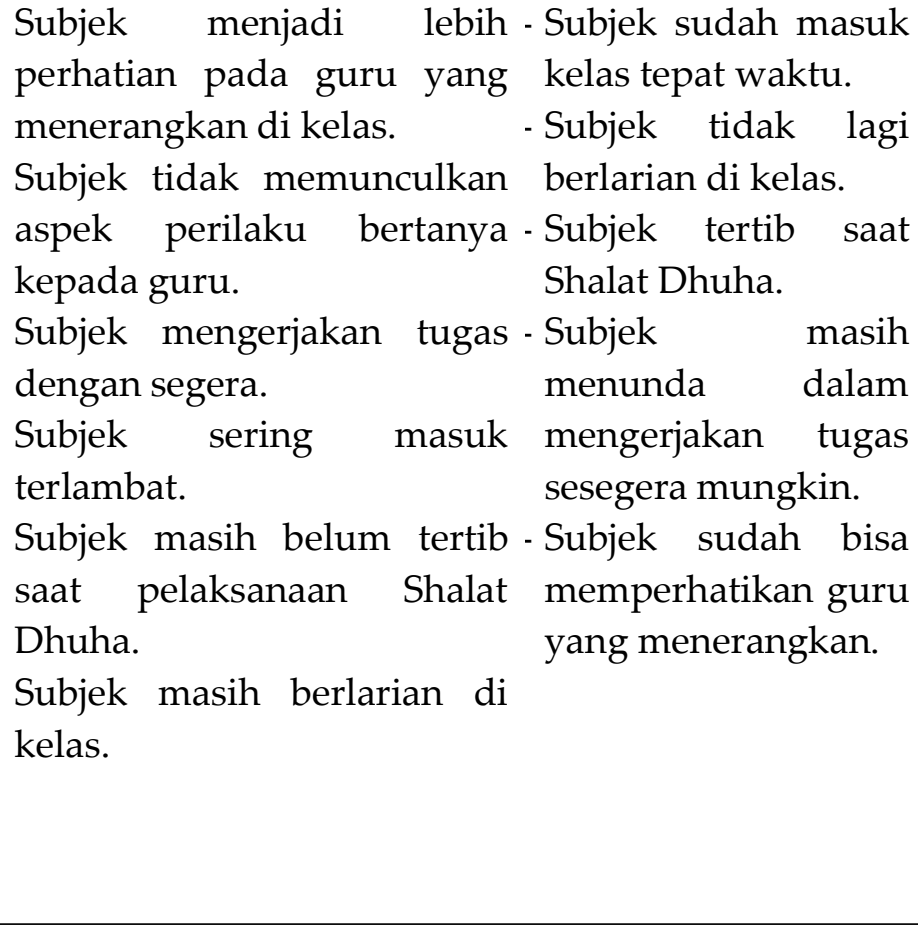 \\
\hline
\end{tabular}

Tabel 2. Hasil Penelitian Subjek 2

\begin{tabular}{|c|c|c|}
\hline Sebelum Intervensi & Masa Intervensi & Setelah Intervensi \\
\hline $\begin{array}{l}\text { Subjek tidak pernah } \\
\text { memperhatikan guru } \\
\text { yang menerangkan di } \\
\text { depan kelas. } \\
\text { Subjek tidak pernah } \\
\text { bertanya mengenai } \\
\text { pelajaran yang tidak dia } \\
\text { mengerti. } \\
\text { Subjek masih menunda } \\
\text { mengerjakan tugas yang } \\
\text { diberikan guru. } \\
\text { Subjek masih masuk } \\
\text { kelas terlambat. } \\
\text { Subjek tidak tertib saat } \\
\text { shalat Dhuha } \\
\text { Subjek masih berlarian } \\
\text { di kelas. }\end{array}$ & $\begin{array}{l}\text { Subjek sudah mulai } \\
\text { memperhatikan guru yang } \\
\text { menerangkan. } \\
\text { Subjek masih belum } \\
\text { bertanya mengenai materi } \\
\text { yang tidak dia pahami } \\
\text { Subjek sudah mulai } \\
\text { mengerjakan tugas yang } \\
\text { diberikan (dengan segera). } \\
\text { Subjek sudah mulai bisa } \\
\text { masuk kelas tepat waktu. } \\
\text { Subjek tertib saat Shalat } \\
\text { Dhuha. } \\
\text { Subjek masih berlarian di } \\
\text { kelas. }\end{array}$ & $\begin{array}{l}\text { Subjek sudah mulai } \\
\text { memperhatikan } \\
\text { guru yang } \\
\text { menerangkan di } \\
\text { depan kelas. } \\
\text { Subjek sudah mulai } \\
\text { bertanya kepada } \\
\text { guru mengenai } \\
\text { materi yang tidak } \\
\text { dia pahami. } \\
\text { Subjek selalu masuk } \\
\text { kelas tepat waktu. } \\
\text { Subjek selalu tertib } \\
\text { saat pelaksanaan } \\
\text { Shalat Dhuha. } \\
\text { Subjek sudah tidak } \\
\text { lagi berlarian di } \\
\text { kelas. }\end{array}$ \\
\hline
\end{tabular}

\section{DISKUSI}

Pada hasil eksperimen, diketahui terdapat adanya pengaruh pemberian penguatan positif pada perilaku sehari-hari siswa. Dari hasil pengamatan sebelum intervensi, diketahui bahwa pada subjek 1, diketahui terdapat adanya perubahan dari pemberian penguatan positif pada perilaku siswa. 
Pada minggu pertama atau pre-test, diketahui jumlah total skor perilaku yang terkumpul adalah 13, dengan nilai rata-rata perilaku adalah 2,6. Rinciannya sebagai berikut: memperhatikan guru yang menerangkan di depan kelas muncul 2 kali, bertanya kepada guru mengenai materi yang tidak dipahami, muncul 1 kali. Subjek 1 mengerjakan tugas yang diberikan guru, muncul 3 kali, masuk kelas tepat waktu muncul 4 kali, dan tidak berlarian di kelas muncul 3 kali.

Pada minggu kedua atau pelaksanaan intervensi, jumlah total skor perilaku yang terkumpul menjadi 18 dengan rincian perilaku: memperhatikan guru yang menerangkan di depan kelas, muncul 4 kali. Mengerjakan tugas yang diberikan oleh guru dengan segera, muncul 5 kali. Masuk kelas tepat waktu, muncul 3 kali (agak menurun dari minggu sebelumnya). Tidak berlarian di kelas muncul 2 kali, dan tertib saat pelaksanaan Shalat Dhuha, muncul 4 kali.

Minggu berikutnya atau post-test, rata-rata nilai menjadi lebih tinggi dari masa sebelum intervensi. Jumlah poin yang terkumpul mencapai 21 poin dengan rincian: subjek memperhatikan guru yang menerangkan di kelas, muncul 4 kali. Bertanya mengenai materi yang tidak dipahami, muncul 1 kali. Dengan segera mengerjakan tugas yang diberikan guru, muncul 4 kali. Masuk kelas tepat waktu, muncul 4 kali. Tertib atau tidak berlarian di kelas, muncul 3 kali, dan tertib saat Shalat Dhuha, muncul 4 kali.

Sementara pada subjek 2, pada minggu pertama pre-test, terkumpul 10 poin, meliputi: 1 kali memperhatikan guru yang menerangkan di depan kelas, 2 kali terlihat mengerjakan tugas yang diberikan guru dengan segera, 2 kali masuk kelas tepat waktu, 3 kali tertib atau tidak berlarian di kelas, 2 kali tertib Shalat Dhuha.

Disiplin dapat diartikan penunjukan sikap dalam perilaku, yang sesuai dengan peraturan dalam instansi, baik yang tertulis maupun tidak (Nitisemito, 1982). Juga bisa diartikan berkembangnya mekanisme internal dari dalam diri individu sehingga mereka dapat mengatur perilakunya sendiri secara mandiri (Aqib, 2011).

Penguatan positif yang baik, terdiri atas 2 metode, yaitu verbal dan non-verbal. Penguatan positif yang diberikan secara verbal, diantaranya pemberian kalimat seperti: "wah, kamu pinter banget bisa menyelesaikan soal ini dalam waktu singkat!". Sementara penguatan non-verbal, memberikan tepuk tangan kepada siswa setiap kali siswa melakukan tindakan disiplin semisal masuk kelas tepat waktu, tidak mencontek saat ujian.

Ahmed dan Gill (2015) dalam penelitiannya mengemukakan bahwa penguatan positif yang diberikan akan meningkatkan perilaku disiplin pada siswa. Secara umum, siswa akan merasa nyaman diperlakukan secara halus dan diberi pengertian, sebab dia merasa keharusan atau peraturan yang bersifat kaku untuk mengontrol dirinya akan hilang, berganti pemahaman yang baik terhadap aturan tersebut dan bahwa peraturan sekolah yang dibuat akan mendatangkan keuntungan bagi siswa itu sendiri.

Pada guide observasi, diketahui terdapat beberapa aspek yang naik pada perilaku siswa. Hal ini membuktikan penguatan positif yang diberikan setiap hari, memberikan dampak atau pengaruh yang positif pada perilaku siswa. Meski mengalami penurunan pada aspek masuk kelas tepat waktu di minggu intervensi, yang diakibatkan tak tahu bahwa guru masuk kelas serta masih ingin meneruskan bemain, padahal peneliti sudah mengingatkan bahwa saat itu sudah waktunya masuk kelas. Hal ini 
mengindikasikan bahwa siswa masih meremehkan aturan dan belum bisa berperilaku disiplin sepenuhnya.

\section{SIMPULAN DAN IMPLIKASI}

Berdasarkan pemaparan di atas, terdapat pengaruh dari pemberian penguatan positif terhadap perilaku disiplin pada subjek 1 dan tidak banyak pengaruhnya pada subjek 2. Pada skor perilaku yang ditunjukkan sebelum intervensi serta pada saat pelaksanaan intervensi, terdapat peningkatan perilaku sebesar rata-rata 2 poin, atau dua kali kemunculan. Artinya, penguatan positif meningkatkan kedisiplinan siswa.

Implikasi dari penelitian ini dapat menyadarkan para pendidik bahwa ada cara lain yang bisa digunakan dalam mendidik siswa tanpa menimbulkan luka. Pendidik dan orangtua harus menyadari penggunaan penguatan positif pada anak-anak dan menerapkannya jika ingin anak berperilaku disiplin. Selain itu, implikasi lain dari penelitian ini adalah mengingatkan individu akan nilai-nilai atau norma sosial yang berlaku di mata masyarakat, seperti taat pada aturan, menghargai orang lain, juga khusyuk dalam beribadah, sehingga dapat menjadi langkah awal mereka bisa terlatih secara perilaku sebelum siap berperilaku mengikuti aturan dalam masyarakat.

\section{REFERENSI}

Ahmed, M., \& Gill, B. R. (2015). Use of Motivational Expressions As Positive Reinforcement in Learning English At Primary Level in Rural Areas of Pakistan. International Journal of English Teaching, 3(1), 32-47.

Alwisol, M. (2009). Psikologi kepribadian (Ed. revisi). Malang: UMM Press.

Arikunto, Suharsimi. (2006). Metodologi penelitian. Yogyakarta: Bina Aksara.

Aqib, Z. (2011). Pendidikan karakter: Membangun perilaku positif anak bangsa. Yrama Widya.

Chaplin, J. P. (2011). Kamus lengkap psikologi. Jakarta: PT. Raja Grafindo Persada.

Cote, D. L., \& Sparks, S. L. (2016). Positive behavior supports in middle and secondary school. Autism spectrum disorders: Identification, education, and treatment, 312 .

Dolet, U. (2003). Manajemen disiplin. Jakarta: Grasindo.

Fallon, L. M., McCarthy, S. R., \& Sanetti, L. M. H. (2014). School-wide positive behavior support (SWPBS) in the classroom: Assessing perceived challenges to consistent implementation in Connecticut schools. Education and Treatment of Children, 37(1), 1-24.

Hamid, D. (2009). Kemampuan dasar mengajar. Bandung. Alfabeta.

Hox, J. J., Moerbeek, M., \& Van de Schoot, R. (2017). Multilevel analysis: Techniques and applications. Routledge.

Hulac, D., Benson, N., Nesmith, M. C., \& Wollersheim Shervey, S. (2016). Using variable interval reinforcement schedules to support students in the classroom: An introduction with illustrative examples. Journal of Educational Research and Practice, 6(1), 6.

Irham, M., \& Wiyani, N. A. (2013). Psikologi Pendidikan: Teori dan Aplikasi dalam proses pembelajaran. Yogyakarta: Ar-Ruzz Media.

Ladouceur, C. D., Schlund, M. W., \& Segreti, A.-M. (2018). Positive reinforcement modulates fronto-limbic systems subserving emotional interference in adolescents. Behavioural Brain Research, 338, 109-117.

Lassen, S. R., Steele, M. M., \& Sailor, W. (2006). The relationship of school-wide positive behavior support to academic achievement in AN Urban middle school. Psychology in the Schools, 43(6), 701-712. https://doi.org/10.1002/pits.20177 
Maag, J. W. (2001). EBSCOhost: Rewarded by punishment: Reflections on the disuse of positive reinforcement. 67(2). Retrieved from http://web.ebscohost.com.proxy.lib.utk.edu:90/ehost/pdfviewer/pdfviewer?sid=48d479cf1f84-4a49-ad6a-0f3d55782d85\%40sessionmgr113\&vid=4\&hid=124

Majid, A. (2012). Perencanaan pembelajaran. Bandung: PT. Remaja Rosdakarya).

Morin, Danielle, "The effects of inclusion and positive reinforcement within the classroom" (2017). Honors Program Contracts. 4 from htp://scholarworks.merrimack.edu/honors_component/4

Mulder, R. (n.d.). 1.2 Reducing Students' Littering Behaviour by Application of Persuasive Techniques. Published 2016, 17.

Nitisemito, A. S. (1982). Manajemen personalia (Manajemen sumber daya manusia). Ghalia Indonesia.

Prijodarminto, S. (1994). Disiplin kiat menuju sukses. Cetakan keempat. Jakarta: PT Abadi.

Putri, A.W. (2018, March 29). Menimbang efektivitas hukuman pada anak. Retrieved February 20, 2019, from https://tirto.id/menimbang-efektivitas-hukuman-pada-anak-cGBu

Rumfola, L. (2017). Positive reinforcement positively helps students in the classroom. Retrieved from http://digitalcommons.brockport.edu/ehd_theses/786

Sarlito, W. S. (1978). Berkenalan dengan aliran-aliran dan tokoh-tokoh psikologi. Jakarta. PT Bulan Bintang.

Santrock, J. W. (2011). Perkembangan anak. Terjemahan: Sarah G. B) Jakarta: Erlangga.

Smith, T. W. (1983). An experimental comparison of clustered and scattered scale items. Social Psychology Quarterly, 46(2), 163-168.

Soemanto, W. (1998). Psikologi pendidikan. Bandung: Rineka Cipta.

Sugiyono, W. E. (2001). Statistika penelitian dan aplikasinya dengan SPSS 10.0 for Windows. Bandung: Alfabeta.

Sutikno, S. (2010). Pengelolaan pendidikan tinjauan umum dan konsep islami. Bandung: Prospect.

Thorndike, E. L. (1927). The law of effect. The American Journal of Psychology, 39(1/4), 212-222.

Tulus, T. (2004). Peran dan disiplin pada perilaku dan prestasi siswa. Jakarta: Grasindo.

Yasmin (2009, March 9 th). Cara asyik ajari anak disiplin tanpa drama. Retrieved March 10, 2019, from https://www.liputan6.com/health/read/3907687/7-cara-asyik-ajari-anak-disiplintanpa-

drama?related=dable\&utm expid=.9Z4i5ypGQeGiS7w9arwTvQ.1\&utm referrer=https\% 3A\%2F\%2Fwww.google.com $\% 2 \mathrm{~F}$

Zubaedi, D. P. K. (2011). Konsepsi dan aplikasinya dalam lembaga pendidikan. Jakarta: Kencana. 